\title{
CHARACTERIZATION OF THE ORGANIZATIONAL INSTRUMENTS OF THE PINE NUT PRODUCTIVE CHAIN IN RS: A COMPARISON WITH BRAZILIAN CHESTNUTS IN ACRE
}

\author{
Elke Lima Santos ${ }^{1 *}$, Débora Luana Pasa ${ }^{1}$, Luana de Campos de Jesus ${ }^{1}$, Jorge Antonio de Farias ${ }^{1}$ \\ ${ }^{1 *}$ Federal University of Santa Maria, Graduate Program in Forestry Engineering, Santa Maria, Rio Grande do Sul, Brazil - \\ elke.lima@hotmail.com*; debora.pasa@gmail.com; luanacamppos@yahoo.com; fariasufsm@gmail.com
}

Received for publication: 24/10/2019 - Accepted for publication: 25/08/2020

\begin{abstract}
Resumo
Caracterização dos instrumentos organizacionais da cadeia produtiva do pinhão no RS: uma comparação com a castanha do brasil no Acre. O Brasil possui uma vasta diversidade de recursos naturais, os quais são importantes no contexto econômico e social de muitas famílias, identificados por meio de produtos florestais não madeireiros (PFNM), entre eles a Castanha, no norte, e o Pinhão, no sul do Brasil. Assim, o objetivo do trabalho foi analisar a cadeia produtiva da castanha-do-brasil a fim de estabelecer e identificar potencialidades existentes na cadeia da castanha que possam ser utilizadas para a promoção da cadeia do pinhão no âmbito social, econômico e ambiental. O estudo foi realizado por meio da aplicação de questionário aberto, tendo como público-alvo representantes ligados à comercialização e pesquisa de ambos os produtos florestais. Como principal resultado, evidencia-se que o pinhão tem uma cadeia produtiva incompleta, apresentando-se como um produto com representatividade secundária junto à formação da renda dos produtores, o que contribui para que a estrutura da comercialização do pinhão seja incipiente. Além disso, a falta de organização social para o extrativismo é o responsável pela não consolidação da cadeia, aliado ao incipiente processo de industrialização e beneficiamento do PFNM pinhão, que limita a agregação de valor do produto. Há necessidade de maior interesse e atenção da parte do poder público com ações que envolvam entidades que possam assistir nas mais diferentes esferas, bem como conceder assistência técnica, pesquisas e apoio financeiro.

Palavras-chave: Comercialização. Produtos Florestais Não Madeireiros. Araucaria angustifolia.
\end{abstract}

\section{Abstract}

Brazil has a vast diversity of natural resources, which are important in the economic and social context of many families, identified through non-wood forest products (NWFP), among them chestnuts, in the north, and pine nut, in the south of the country. Thus, the objective of the work was to analyze the productive chain of the Brazilian chestnuts in order to establish and identify potentialities existing in its productive chain that can be used to promote the pine nut productive chain in the social, economic and environmental spheres. The study was carried out through the application of an open questionnaire, having as target audience representatives linked to the commercialization and research of both forest products. As a main result, it is evident that the pine nut has an incomplete production chain, presenting itself as a product with secondary representation in the formation of farmers' income, which contributes to the structure of pine nut commercialization being incipient. In addition, the lack of social organization for extractivism is responsible for the non-consolidation of the chain, coupled with the incipient process of industrialization and processing of the pine nut. which limits the added value of the product. There is a need for greater interest and attention on the part of the government with actions involving entities that can assist in the most different spheres, as well as providing technical assistance, research, and financial support.

Keywords: Commercialization. Non-Wood Forest Products. Araucaria angustifolia.

\section{INTRODUCTION}

Brazil is a country that has a diversity of biomes and forest formations. This is possible thanks to the large amount of natural resources available, which makes them even more relevant and important for their regions of occurrence, as is the case with two non-wood forest products (NWFPs) endemic to regions at the ends of the country: pine nuts and Brazilian chestnuts.

Pine nuts occurs in the southern region, in the Atlantic Forest Biome, originating from Araucaria angustifolia (Bert.) O. Kuntze, popularly known as Araucaria in Brazil or Pine, a species threatened with extinction because it was the target of intense exploitation in the past due to its timber potential.

In the historical context, the exploration of pine nuts, according to Nodari and Klug (2012), is a practice used by the indigenous peoples of southern Brazil, who disputed among themselves the araucarias, which served as their food base, thus having greater control of its management. Even today they are widely consumed during autumn and winter, especially in the June festivals in the region (FIGUEIREDO et al., 2011).

At the other end of the country, in the northern region, covered by the Amazon biome, many resources are extracted and traded. In this, Bertholletia excelsa Humb. \& Bonpl., popularly known as Brazilian chestnut tree,

FLORESTA, Curitiba, PR, v. 51, n. 2, p. 466-475, abril/jun 2021.

Santos, E.L. et.al.

ISSN eletrônico 1982-4688

DOI: $10.5380 /$ rf.v51 i2. 69864 
produces Brazilian chestnuts and stands out for its wide area of occurrence, high production index and great market acceptance.

Today, the chestnut is permanently the basis of income for hundreds of extractive families, who have a high degree of social organization and support from organizations at the state, federal and international levels. Its commercialization has assistance due to its nutritional properties, but also due to the social appeal involved in the production chain, as it is a product from the Amazon, which is collected, processed, and marketed by extractivists whose main source of income is this activity. Among the NWFPs, Brazilian chestnuts stand out for the existence of an internationally established market, being the only commercialized seed that is harvested exclusively in natural forests (PERES et al., 2003). In colonization by the Portuguese, when they conquered Grão-Pará, the Brazilian chestnut were already found as an important element of indigenous food and as a complement to enhance the taste of porridges and manioc flour. At the time of colonization, Europeans adhered to this food habit and took the chestnut to Europe (WADT e KAINER, 2009).

Considering the reality of the situation that affects the productive chains of pine nuts and Brazilian chestnuts, what differentiates them is the economic importance and the model of organization and commercialization of both. Thus, the design of the production chain scenario can provide the definition of the existing strengths and weaknesses to promote their improvement.

In view of the above, the objective was to characterize and compare the chestnut production chain, already consolidated, with the form of commercialization existing in the NWFP pine nut. Allied to this, the aim was to present strategies that can help in the construction and consolidation of a pine nut productive chain, based on the experience of extracting chestnuts.

\section{MATERIAL AND METHODS}

\section{Location and description of the studied areas}

For this study, a survey of the area of occurrence of the Mixed Ombrophilous Forest (MOF) was carried out, as it is the forest formation in which Araucaria predominates. The Mixed Ombrophilous Forest is a phytogeographic typology that occurs in the South of Brazil and can be divided into four sub formations: Alluvial, Submontane, Montane and Super montane, all occurring in Rio Grande do Sul (RS) (IBGE, 2012).

According to Rambo (1956), the pine tree occurs along the entire upper free edge of the plateau, starting from the north of Santa Maria to the extreme northeast; in the upper valleys and at the headwaters of the Caí, Taquari, Antas, Jacuí and Pelotas rivers; in isolated groups or dense societies, in the small forests spread throughout the plateau; in solitary individuals in the middle of the field, as seen east of Cruz Alta; mixed with the virgin forest of Alto Uruguai, north of Passo Fundo and Lagoa Vermelha.

According to Wadt and Kainer (2009), in Brazil, the chestnut occurs in Pará (next to the Trombetas, Tapajós, Xingu, Tocantins and tributaries rivers), Amazonas (next to the Amazon, Madeira, Negro, Purus and tributaries rivers), Acre (next to the Acre, Purus, Iaco and Abunã rivers), Maranhão (constituted area of the Legal Amazon) and Mato Grosso (near the Araguaia river).

The chestnut study was carried out in the State of Acre, where chestnut clusters occur in the municipalities of Sena Madureira, Rio Branco, Plácido de Castro, Xapuri, Brasiléia and Assis Brasil.

\section{Data Collect}

To obtain information about the historical conditions, current scenario, production, commercialization, and legislation of the referred NWFP, 2 forms were prepared, with 18 and 20 open questions (chestnuts and pine nuts, respectively), presented in an online form on Google Docs, these arranged in 3 topics, as described below:

a) History of exploration, production, and forms of commercialization: Addresses questions about production, commercialization, agents, and processing and aims to verify unusual and common points between the pine nut marketing chain and the Brazilian chestnut production chain.

b) Social Organizations and Public Policies: refers to information about public or private institutions in maintaining or consolidating the NWFPs chains. This topic aimed to present the panorama of incentives and public policies applied to the NWFP in the two different regions of the country, in addition to generating information relevant to the debate on the sustainable management of the NWFP in the MOF.

c) Legislation and future perspectives: It discuss information related to incentives and social perception regarding the commercialization and use of products, aiming to suggest alternatives for the strengthening of the pine nut marketing chain.

The application of the forms took place between the second half of 2016 and the second half of 2017.

Still, as shown in the organization chart in Figure 1, four segments of different scenarios were formed, where it was found, among these, which institutions were related or that functioned as agents in the chestnut production and pine nut marketing chains.

FLORESTA, Curitiba, PR, v. 51, n. 2, p. 466-475, abril/jun 2021.

Santos, E.L. et.al.

ISSN eletrônico 1982-4688

DOI: $10.5380 /$ rf.v51 i2. 69864 


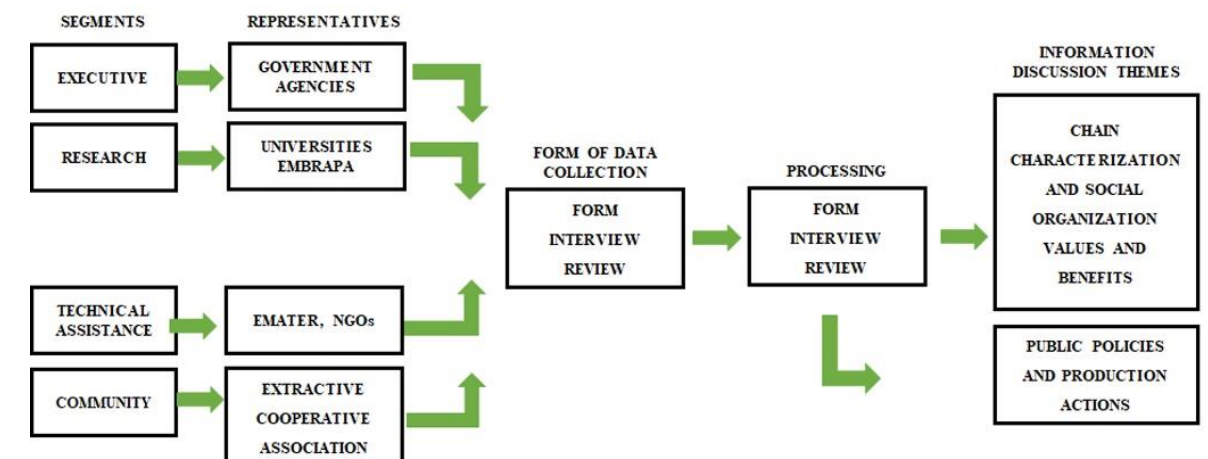

Figure 1. Organization chart of stages of the methodology.

Figura 1. Organograma de etapas da metodologia.

Each of the segments has its representatives who have been defined as key representatives. These came from institutions that have greater representation at the municipal, state, or regional level, regarding actions involving the production and marketing of the two non-wood forest products from extractivism.

In relation to pine nuts, in the executive segment, a representative from the Secretariat for the Environment and Sustainable Development (SEMA) and one from the Chico Mendes Institute for Biodiversity Conservation (ICMBio) were interviewed. In the research segment, the Federal University of Santa Maria, and the Brazilian Agricultural Research Corporation (Embrapa de Colombo, Paraná) were interviewed, both with one interviewee. For the technical assistance segment, the interviews were conducted with EMATER of Rio Grande do Sul, Center for Popular Alternative Technologies (CETAP) and Center for Environmental References (ANAMA), all in this segment with one interviewee each. For the society segment, a representative of a company was interviewed.

As for the chestnut, in the executive segment, two representatives from ICMBio and two from the research segment of the Federal University of Acre were interviewed. To represent the society segment, an extractivist from the extractive reserve Chico Mendes-AC was interviewed and finally for the technical assistance segment, it was decided to contact EMATER in the state of Acre, but we had no feedback. It was defined that each segment should have one or two representatives because there are no more than two institutions per segment that had a high representation.

The analysis was carried out based on primary data from the questionnaires, and secondary data where economic and production information were verified, to better characterize the expressiveness of each of the NWFPs. The qualitative research method was assumed, exploring the deepening of the understanding of the phenomenon through interviews and direct observation.

\section{RESULTS}

\section{Characterization of the chains and social organization}

Nineteen municipalities were cited as the main producers of pine nuts in RS, among them the municipality of São Francisco de Paula, in Campos de Cima da Serra, highlighted by $100 \%$ of respondents, followed by municipalities in the Serra Gaúcha region, especially Caxias do Sul.

The forms of commercialization are mainly in natura for $62.5 \%$ of the interviewees; for the others, there has been a slight change, where it is possible to observe the pine nuts minimally processed in the form of peeled, cooked and ground.

For $100 \%$ of the interviewees, the product is sold directly from the collectors to the final consumer or from middlemen to the final consumer, mainly in local shops and in tents on the edges of highways. Even though all respondents mention the occurrence of direct trade, it should also be noted that $50 \%$ of them comment that trade occurs through street vendors, who travel in different cities making the sale and $37.5 \%$ mention that there is sale in markets and fruit shops. Only $12.5 \%$ of respondents mentioned about marketing via cooperatives, which were not identified.

The key interviewees' reports regarding the links participating in the pine nut chain define extractivists as those who collect it, middlemen as responsible for the wholesale purchase, and retail buyers and sellers (Figure 2). 


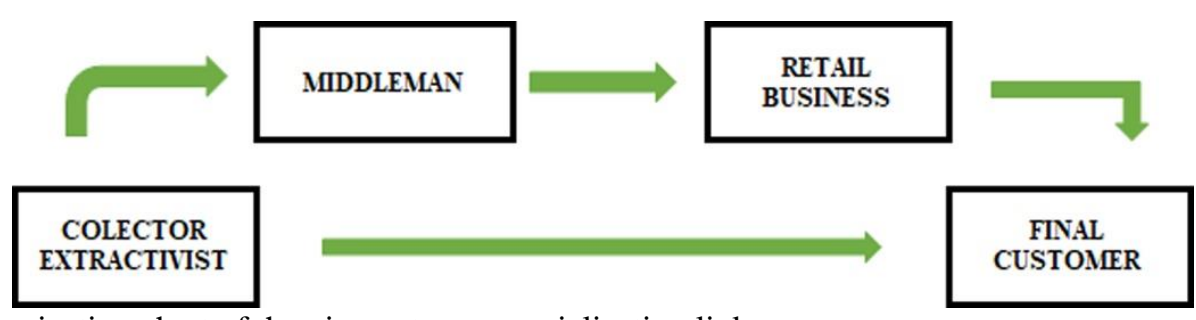

Figure 2. Organization chart of the pine nut commercialization links.

Figura 2. Organograma dos elos da comercialização do pinhão.

There is also evidence of a variation in the prices of products, mainly due to fluctuations in production, with greater production entailing a lower price and vice versa. In addition, different prices are observed according to the places of sale. According to the interviewees, the price per kilogram of pine nuts sold by the collector in 2017 ranged from $\mathrm{R} \$ 2.50$ to $\mathrm{R} \$ 5.00 \mathrm{a} \mathrm{kg}$ in the period from April to June. In retail trade, this value reaches $\mathrm{R} \$$ 15.00 and in the Supply Center (CEASA) the value is $\mathrm{R} \$ 6.40$ per $\mathrm{kg}$ in periods of greater commercialization, from April to June, for the same year.

Regarding the ways of adding value, it is evident by $100 \%$ of the interviewees that the introduction of pine nuts in local gastronomy must occur, since it can be used in sweet and savory dishes, in addition to being able to be processed in the form of paçoca (a kind of flour resulting from the mixture of various ingredients pounded together in the pestle) and flour.

In the case of Brazilian chestnuts, in the state of Acre, seven of the 22 cities in the state were mentioned as producers and traders, namely: Brasiléia, Xapuri, Sena Madureira, Rio Branco, Assis Brasil and Capixaba, Epitaciolândia, Bujari, Porto Acre, Acrelândia and Senador Guiomard. The main forms of commercialization are in natura and chestnut with dry peel and peeled and dry chestnut.

The actors in the chain (Figure 3) are producers (extractivists), associations of extractivists, whose purpose is to bring together production and cooperatives, which aim to purchase the chestnut from the associations and later sell to distributors in the southeast of the country, especially, São Paulo, and large purchasing companies such as Nestlé and Nutrimental, which use the chestnut as a raw material for various foods and sell the product to the final consumer. It cannot be ruled out that the intermediary is present. According to the interviewees, most of the Brazilian chestnut comes from the state of Acre and is traded in natura, either through direct wholesale or sale to the Central Cooperative of Extractive Trade in Acre (COOPERACRE), from where processing is performed. The chestnut, after being sold to the cooperative, is processed and transformed into chestnut with dry peel and peeled chestnut, in addition to laminated chestnut, being available for sale in various types of packaging and quantities.

Regarding changes in production and marketing, $75 \%$ of respondents report that there have been no significant changes in these aspects. The creation of COOPERACRE in 2001 stabilized and improved the chestnut trade in Acre. However, there is still the form of commercialization known as "marretagem", in which many extractivists choose to sell the chestnut to the market of the neighboring country, Bolivia, thus reducing the amount of product received by the cooperative, which may contribute to the decrease in the offer to the national and international market, due to the decrease in the quantity of product available.

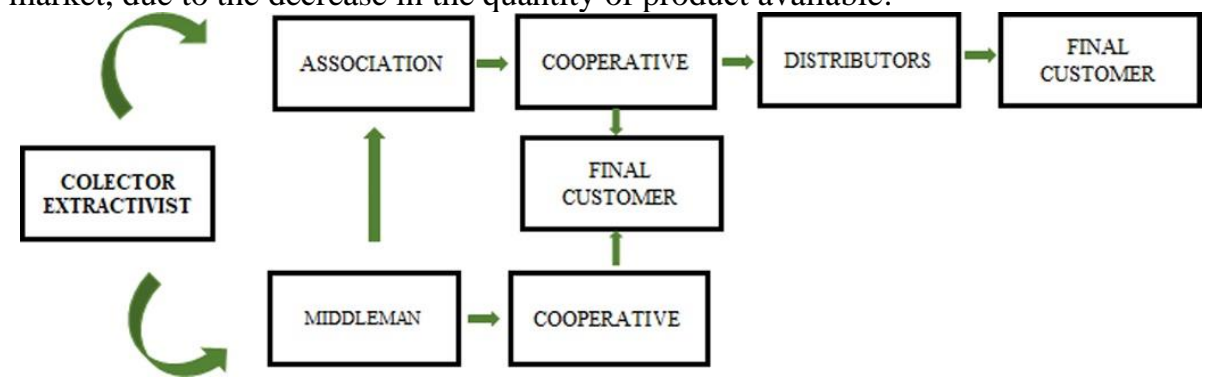

Figure 3: Organization chart of the links of the chestnut production chain.

Figura 3: Organograma dos elos da cadeia produtiva da castanha.

Like pine nuts, chestnut, according to the interviewees, also varies in the amount produced annually, however, it is sold at a value that encourages collection and especially post-processing sale. In the interview it was possible to verify that in 2017 the chestnut was sold, from the extractivist to the association, in the amount of R $\$$ 55.00 per can (approximately $15 \mathrm{~kg}$ ) and from the association it was sold to the local cooperative by $\mathrm{R} \$ 85.00 \mathrm{a}$ can.

This difference of $\mathrm{R} \$ 30.00$ is returned to the extractivist at the end of the extraction period, however, with a discount of $\mathrm{R} \$ 4.00$ that will remain in the association and of $\mathrm{R} \$ 1.50$ that will be paid to the person

FLORESTA, Curitiba, PR, v. 51, n. 2, p. 466-475, abril/jun 2021.

Santos, E.L. et.al.

ISSN eletrônico 1982-4688

DOI: $10.5380 /$ rf.v51 i2. 69864 
responsible for buying the chestnut from the extractivist and taking it for the association. That is, the total amount that the extractivist receives for the chestnut can is $\mathrm{R} \$ 79.50$, or approximately $\mathrm{R} \$ 5.30$ per $\mathrm{kg}$. Nevertheless, the value practiced in the local trade can reach $\mathrm{R} \$ 30.00$ the $500 \mathrm{~g}$ package vacuum-packed, totaling $\mathrm{R} \$ 60.00$ per $\mathrm{kg}$ after processing.

With the structuring of COOPERACRE, there were significant changes in the valorization of the chestnuts, due to forms of drying and vacuum packaging, and the commercialization of chestnuts with dry peel and peeled and dry chestnuts. Oil extraction and slicing has been taking place on a small scale, with some extractive communities already using good practice techniques that guarantee product quality, from the collection to commercialization (such as maintaining a certain level of humidity to ensure no fungus and other agents that can cause damage to health), with the technical support of non-governmental organizations (NGOs) and cooperatives. In addition, they make the selection and classification of almonds, according to the standard required by the market, guaranteeing the sale. Still, $100 \%$ of the interviewees emphasize that the chestnut already has consolidated trade, what remains to be refined is the improvement of new products such as chestnut oil, chestnut flour, chestnut chips, sweets, and candied chestnut, which according to $50 \%$ of the interviewees, can be promising products for greater added value.

Regarding production, IBGE data brings a total of 75,349 tons of pine nuts traded between 2010 and 2018, with an increase of $65.56 \%$. For Brazilian chestnuts, 330,186 tons were sold between 2010 and 2018 , showing a drop in 2017 after a period of stabilization (Figure 4).

Brazilian chestnut production generated R \$ 55.19 million in 2010, rising to R 130.9 million in 2018 , with a monetary growth of $137.18 \%$ and an annual average of $\mathrm{R} \$ 87,797.44$. As for pine nuts, VBP has been growing year after year, varying from R \$ 9.12 million in 2010 to $\mathrm{R} \$ 24.7$ million in 2018, showing $170.9 \%$ growth with an annual average of $\mathrm{R} \$ 17,778.67$.

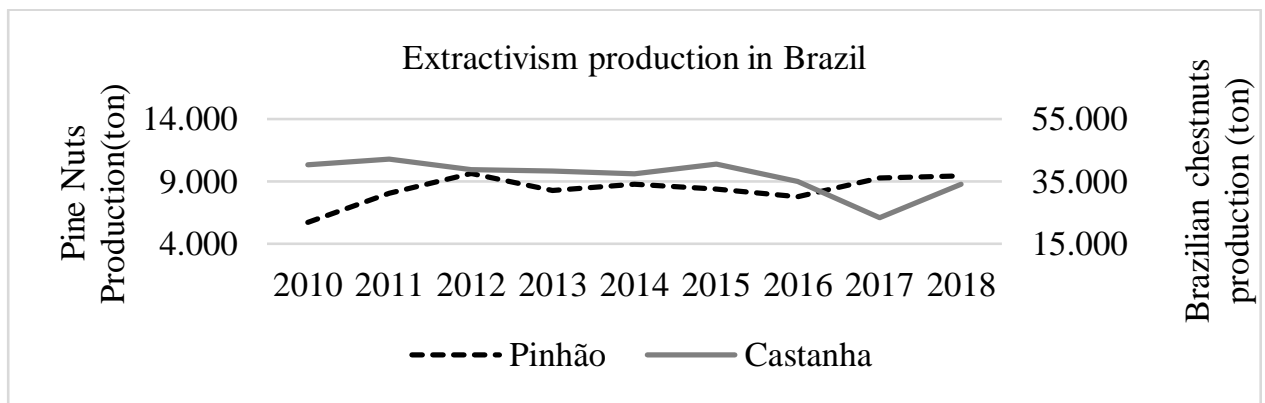

Figure 4: Pine nut and chestnut production in the years 2010 to 2018. Source: Authors, using SIDRA IBGE 2018 as base.

Figura 4: Produção do pinhão e da castanha nos anos de 2010 a 2018. Fonte: Autor baseado em SIDRA IBGE 2018.

Public policies and actions aimed at the production chain.

Of the eight institutional representatives participating in the survey, $62.5 \%$ replied that there are no, and did not exist in the past, policies to encourage the creation or strengthening of a productive chain for pine nuts. The rest, $37.5 \%$, cited the Minimum Price Guarantee Policy for products of socio-biodiversity (PGPM-Bio) and the creation of the Normative Ordinance DC-20, which prohibits the harvesting of pine nuts by cutting down immature pinecones, before April 15, as the only political actions applied to the commercialization of pine nuts.

Pine nuts was the first product from the southern region of Brazil to be included in the PGPM-Bio program, it is a system of delimitation of prices established by the Federal Government, which assigns a minimum price for the commercialization of socio-biodiversity products. Thus, the difference between the marketed value and the value established for the minimum price of the product, which is known as a subsidy, is passed on to the producer or extractivist. Ordinance No. 123, of July 5, 2016, published in the Federal Official Gazette on 07/06/16, annex IV, for the $2016 / 2017$ harvest, establishes the price of $\mathrm{R} \$ 2.64$ per $\mathrm{kg}$, as extractivist makes a sale with a lower value, it must be reimbursed with the value referring to the difference.

However, according to reports by research participants, PGPM-Bio is poorly accessed and does not reach many collectors and farmers who sell pine nuts. On the other hand, the same does not happen with the Brazilian chestnut production chain, in which the PGPM-Bio subsidy is widely disseminated and accessed by the extractive community.

Managers, administrators, and social representatives, when describing public actions aimed at promoting the commercialization of pine nuts, claim that they are unaware of actions regarding the attention given to the product in their areas of operation. Also, according to the interviewees, there is no effective policy that supports

FLORESTA, Curitiba, PR, v. 51, n. 2, p. 466-475, abril/jun 2021.

Santos, E.L. et.al.

ISSN eletrônico 1982-4688

DOI: $10.5380 /$ rf.v51 i2. 69864 
the commercialization of pine nuts and, previously, those that existed were in the way of restricting their use with the idea of preservation. Regarding the entities that were and are currently involved with the commercialization of pine nuts, the interviewees answered that, in the majority, they are the environmental agencies in the sense of restriction. Also, on a small scale, local NGOs focused on environmental preservation were mentioned.

Thus, with the lack of public support for the activity, $75 \%$ of respondents report not believing that the farmer/extractivist will carry out plantations of Araucaria angustifolia. The most commented factor for the characterization of this scenario is the conservative environmental legislation that currently exists, which ends up prohibiting the use of Araucaria wood. This prohibition caused and still causes penalties and fines to farmers and, consequently, in many properties, the producer ends up destroying young plants to avoid future problems with the species. In addition, another important factor to be considered is the long cycle to start collecting pine nuts (between 12 and 20 years) and for the use of wood.

However, even though they do not believe that greater Araucaria tree plantations will occur, $100 \%$ of the interviewees report that there is an economic benefit and profitability with extractivism, however this should be used only as a complement of income to the producer and not as the main income.

Regarding the interviewees' perception of the political attention given to the commercialization of Brazilian chestnuts, $100 \%$ of the interviewees cited some action that they considered important for the commercialization of the chestnut to take place effectively. Among them, the Minimum Price Guarantee Policy (PGPM-Bio) was mentioned, a government subsidy on the sale with the supply of working capital to the largest buyer, in this case, COOPERACRE. In addition, organizational assistance from the government and the cooperative was mentioned regarding the physical structure necessary for processing. It was reported that there is a greater attention given by the State Government of Acre and COOPERACRE, mainly regarding the infrastructure with the creation of plants to process the product. Further information on public actions and policies can be seen in Table 1.

Table 1. Policies and legislation that aim to consolidate the Brazilian chestnut and pine nut production chains. Tabela 1. Políticas e legislação voltadas para a consolidação da cadeia produtiva de castanha-do-brasil e pinhão.

\begin{tabular}{|c|c|c|c|}
\hline Product & Actions/Policies and Legislation & Year & Accountable \\
\hline Chestnut & $\begin{array}{c}\text { Minimum Price Guarantee Policy for Socio } \\
\text { Biodiversity Products (PGPM-Bio) }\end{array}$ & $2009 *$ & $\begin{array}{c}\text { National Supply Company } \\
\text { (CONAB) }\end{array}$ \\
\hline Chestnut & $\begin{array}{l}\text { National Plan for the Safety and Quality of } \\
\text { Products of Plant Origin (PNSQV) }\end{array}$ & 2004 & $\begin{array}{c}\text { Ministry of Agriculture, } \\
\text { Livestock and Supply / } \\
\text { World Trade Organization } \\
\text { (MAPA/OMC) }\end{array}$ \\
\hline Chestnut & Capitalization of the cooperatives & 2009 -Today & $\begin{array}{c}\text { Federal } \\
\text { Government/CONAB }\end{array}$ \\
\hline Pine nut & Normative Ordinance DC-20 & 1976 & $\begin{array}{l}\text { Brazilian Institute for } \\
\text { Forestry Development } \\
\text { (IBDF) }\end{array}$ \\
\hline Pine nut & (PGPM-Bio) & $2009 *$ & CONAB \\
\hline
\end{tabular}

Some of the key interviewees, referring to the consolidation of the chestnut extraction activity, highlighted that there is the support of international institutions represented by NGOs with offices in the Amazon, federal, state, and municipal public bodies, in addition to research institutions such as Universities and EMBRAPA, who also mention the relevant and necessary work carried out by civil society organizations.

However, even with government assistance and incentive actions, 50\% of the interviewees believe that, even if they had the opportunity, the extractive producer would not plant chestnut trees due to its long cycle to start production and because there is still no mastery over technology related to chestnut germination and storage. Even so, $100 \%$ of the interviewees point out that the chestnut brings important economic benefits for the entire region, generating jobs and income for several sectors, from the extraction workers to the traders.

\section{DISCUSSION}

\section{Characterization of chains and social organization}

Considering the form of trade that is understood as the production chain, it is possible to define two types of commercialization of products from extraction, as described by Silva and Miguel (2017): through long chains or short chains. 
The production and commercialization of pine nuts in Rio Grande do Sul can take place in two forms of trade, since the trajectory that the product travels and the sectors involved in different market levels can be different, and purchase and sale should be considered of the product and the transformations undergone by him during this trajectory.

The commercialization scenario exposed by Silva and Miguel (2017) reports that the local short chains are schemes in which the product has no intermediary, that is, it is purchased directly from the producer by the consumer, and the families that maintain the extractive activity of the pine nuts are also the ones that make direct sales to the consumer, demonstrating, with this, that there is no added value of the product through the processing, being sold almost entirely in natura form. The same authors show that the pine nut, when sold in short chains, is sold at a higher price due to the absence of intermediaries and the pre-selection of the pine nuts that the producers make, when the sale is only in natura.

The chestnut chain can also be short or long, since the extractivist (or the association of them) can sell the direct production to the consumer market or to cooperatives, however, what differentiates it from the commercialization of pine nuts is its consolidation in the national and international market and the largest industrial process, which maintains the demand for the product and with higher prices. This consolidation is related to the added value of the chestnut through the processing and due to the high nutritional value of the almond due to its composition in lipids, proteins, and vitamins, mainly vitamin $\mathrm{B}$, in addition to appreciable amounts of minerals (GUTIERREZ et al., 1997).

In addition, the economic importance of the NWFPs is also emphasized. In 2018, Brazilian chestnuts generated R\$ 130.9 million, values that allowed the survival and improvement in the quality of life of many extractivists who live exclusively on this income. Also, according to the Monthly Conjuncture report on Brazilian chestnuts issued by the National Supply Company (CONAB) (Apr/2012), the revenues generated from the exports of the chestnuts were around US\$ 6.5 million and the main buyers of the benefited product, with and without shell, are: United States, United Kingdom and Germany. Bolivia is still one of the main buyers of Brazilian chestnuts with shell, acquired mainly from the state of Acre, which is the largest Brazilian producer, and has natural advantages due to its geographical proximity to this main buyer (MORET; BARBOSA, 2016).

As for pine nuts, VBP has been prospering years after year, showing that the growth rate of it is faster than that of Brazilian chestnuts, due to the increase in the commercialization of the product in recent years, which may be related to a slight, but growing, appreciation of the NWFP in Brazil.

Thomas et al. (2014) points out that in relation to the chestnut, the seeds, which are predominantly harvested in natural forests, are commercialized mainly peeled and fresh, or peeled and dehydrated, to favor their conservation, as also identified in this research. The flow of commercialization of pine nuts is essentially characterized by the extremely low degree of industrialization, basically due to cultural aspects, restrictions dictated by seasonality and the quantity produced, in addition to its physiological characteristics that confer a short period of viability (DANNER et al., 2012), which according to CAÇOLA et al., (2006) can reach 180 days with adequate humidity.

The irregularity in the quantity offered each harvest discourages the extractive collector from investing financial resources, dedication, and time in the commercialization of the pine nuts. Still, due to the lack of technologies for its natural conservation and industrial processing, it does not have a significant consumption by the population (PERALTA et al., 2016).

In Rio Grande do Sul, agricultural and livestock activities are of great economic and social importance, and, according to the key interviewees, this fact helps activities such as extraction to remain on the sidelines, being carried out with emphasis on the harvest season, not having other type of incentive to improve the product in the off-season, causing the market to remain stagnant. These cultural issues make it difficult for producers to identify themselves as extractivists because they practice so many other activities and not only the collection of pine nuts or other non-wood forest products, which is not the case with extractivism products in northern Brazil. The commercialization ratio of pine nuts is observed, which is $76.95 \%$, on average, less expressive than commercialization of chestnut, as shown by IBGE data between 2010 and 2018 (IBGE, 2018)

It is noteworthy that, under natural conditions, chestnut trees start fruit production only between 73 and 93 years old, whose production is maximum only after 240 years of age (SCHÖNGART et al., 2015). In plantations, the reproductive age according to Ferreira and Tonini (2009) is twelve years. Salomão (2014) comments that planting chestnuts has been studied and improved in recent years, but they are not yet implemented with the desired satisfaction. In relation to this factor, Araucaria has an advantage, since its reproductive cycle in a natural environment is on average 20 years old (SANT'ANNA et al., 2013) and in planting it is possible to identify reproduction already aged $12-15$ years according to Zanette et al. (2017).

Even though it is a non-wood forest product still in the process of building a chain, the extraction of pine nuts presents an alternative income for family farming as well as a source of food. Pine nuts becomes relevant, above all, for families that work in the form of rural society or day laborers in the fields, because during the winter,

FLORESTA, Curitiba, PR, v. 51, n. 2, p. 466-475, abril/jun 2021.

Santos, E.L. et.al.

ISSN eletrônico 1982-4688

DOI: $10.5380 /$ rf.v51 i2. 69864 
when work in the fields is reduced, families can obtain extra income. For those who have other sources of income, pine nuts are now seen as a "reserve".

There is a need to initially develop strategies to formalize the pine nut extractivism activity in Rio Grande do Sul. Among the strategies, like the chestnut production chain, the cooperative organization of extractivists presents itself as an alternative to the growth and structuring of the base of the chain. Nonetheless, for pine nuts, the problem goes beyond non-organization in association or cooperative. It is necessary to instigate the producer that the commercialization of this non-wood forest product is important and profitable, like the extractivists from the north of the country.

In this way, it is possible to apply the term "productive chain" for chestnuts since the product undergoes transformation until its final constitution and placing on the market. However, the concept cannot be applied in its integral form to pine nuts. It is noteworthy that not all the stages that characterize the complete production chain occur, because between the extraction worker and the buyer, there is, generally, only the trade stage of the product in natura. However, the consolidation of processing and transformation techniques, which can add value to the product, may allow trade not to be restricted only to the seasonality of the season.

Public policies and actions aimed at the pine nut and chestnut production chains.

A contrasting reality between the two products is evident. It can be inferred that the commercialization of pine nuts is neglected as regards the provision of public policy measures and actions aimed at transforming the simplified chain into a consolidated chain. It is worth mentioning that the Normative Ordinance DC-20 prevents the collection of pine nuts as soon as the pinecones are ripe, thus becoming an obstacle to development. With the lack of access to PGPM-Bio, collectors lose an opportunity to value the product and end up selling it to middlemen who pay an amount well below what is stipulated by law.

PGPM Bio, despite the limitations related to the minimum price to the maximum subsidy ceiling and the low access on the part of extractivists, is a public policy that helps in the conservation using biodiversity products. When the extractivist receives a fairer remuneration, he tends to conserve the species that are being extracted. The difficulty of access to information and training, as well as the complex bureaucracy imposed by the State, are barriers that need to be overcome so that PGPM Bio can reach a greater number of extractivists. The presence of an articulating entity that assists in the organization of documents proved to be fundamental.

As this policy is recent, new adjustments should occur over time and may have a favorable influence on the dynamics of the production chain, especially considering that the informality in marketing is high (MAGNANTI, 2016). Public policies that directly interfere in the pricing of products tend to have a positive effect in increasing the legalization of activities.

Currently, a positive factor for the prospects of increasing the commercialization of pine nuts is its inclusion in the Acquisition and Food Program - PAA, in which the purchase of food produced by family agriculture occurs, without the need for bidding. The purchase of these foods is intended for people in situations of food and nutritional insecurity and for those served by the social assistance network and public food and nutrition facilities. This program is an opportunity to include pine nuts in the daily diet of the local and regional population.

However, even with the PAA, it is evident that there are no government institutions that work to strengthen the pine nut chain in relation to the structuring of the product's commercialization. This demonstrates the lack of interest on the part of the public authorities and most of the collectors involved in transforming the collection of pine nuts into a formal economic activity. As for the Brazilian chestnut, the organization of extraction and commercialization is widely discussed and studied. This is due to the tradition and financial dependence that extractivists have on this product, a fact that also contributes for political attention to be given to this activity and, with this, motivates extractivists to remain with the activity as their main source of income.

In Acre, for the consolidation of the chestnut chain, several entities are present, playing the most different roles, whether in terms of technical assistance, legal, business, or financial assistance. Wadt and Kainer (2009) state that the greatest incentive action by the federal government to boost the commercialization of chestnuts was the allocation of resources for the advance purchase of the product, via CONAB, which capitalized the cooperatives, thus favoring the relationship between the government and the producers.

According to Barbosa (2015), the State of Acre with government incentives and non-governmental institutions, through COOPERACRE, has been changing the export scenario for chestnuts with shell since 2005. COOPERACRE started to add value to the product in natura, which before was almost $100 \%$ exported to the Bolivian market. All efforts made aim to increase, diversify and make the chestnut more accepted in the international market, providing a better economic result in the entire production chain (BARBOSA, 2015).

It is also necessary to consider that the consumption of Brazilian chestnuts carries a sustainable ecological bias that reinforces the intention to conserve the Amazon rainforest. In turn, equal vision and attention should be given to MOF, a naturally occurring phytophysiognomy of Araucaria, as it also has cultural and socioeconomic

FLORESTA, Curitiba, PR, v. 51, n. 2, p. 466-475, abril/jun 2021.

Santos, E.L. et.al.

ISSN eletrônico 1982-4688

DOI: 10.5380/rf.v51 i2. 69864 
representativeness for the population residing in it. However, these factors are still little considered to ensure the interaction of use with the preservation of this phytophysiognomy.

The relations of institutions listed by the key interviewees of both production chains reveal that the attention given to pine nuts related activities is still incipient. When compared to the institutions involved with the chestnut production chain, it shows that this activity is supported in several spheres that range from the attention given to extractivists to the financial incentive granted to the cooperative to make the purchase, in addition to research and technical assistance actions.

One can mention the project "Estradas com Araucária" which aims to conserve the species, implemented in four municipalities in Paraná and Santa Catarina, covering 70 family farms, which plant and care for about 20 thousand araucarias. All producers started to obtain a fixed annual income of, on average, R $\$ 1,000.00$ with the project (PARRON et al., 2015). It is also evident the existence of the Certification for Sustainable Extractive of Native Flora with character of sustainability to the practices regularized by this means. Thus, the State Secretariat for the Environment of Rio Grande do Sul has sought to support projects of research institutions with works associated with the sustainable use of this species, to ensure that the conservation strategy by encouraging its use is effective.

\section{CONCLUSIONS}

- Pine nuts have an incomplete production chain, while chestnuts have a complete production chain.

- The commercialization of pine nuts is incipient and requires organization by civil society.

- Both NWFPs are marketed in short and long chains. However, due to the degree of industrialization of the chestnut, there is a greater trade in long chains. This characteristic makes the chestnut traded nationally and internationally, unlike the pine nut that today has its trade only regionalized.

- Social organization presents itself as an essential action for the growth and structuring of the base of the pine nut chain, as seen in the chestnut chain.

- The creation of associations of extractivists assists in the sale of the product, guaranteeing prices and the formation of cooperatives consolidate the processing and sale to the foreign market. They can also be links and visibility to seek financial incentives for the implementation of processing and trade technology, as well as to encourage public policies aimed at preserving Araucaria through use, which are also necessary demands for the consolidation of productive chains of the NWFPs.

\section{REFERENCES}

BARBOSA, M. Boas práticas na cadeia produtiva da castanha do brasil: um estudo comparativo nas reservas extrativistas chico mendes e rio ouro preto. Novas Edições Acadêmicas, Letônia, 2015.

CAÇOLA, Á. V. et al. Qualidade fisiológica de sementes de Araucaria angustifolia (Bertol.) Kuntze submetidas a diferentes condições de armazenamento e a escarificação. Ciência Florestal, v. 16, n. 4, p. 391-398, 2006.

CONAB. Companhia Nacional de Abastecimento. Pinhão (semente): Conjuntura Especial. Brasília, 2014. p. 21 Available

:http://www.conab.gov.br/OlalaCMS/uploads/arquivos/14_09_09_12_36_06_pinhaosementesetembro_2014.pdf. Accessed in 09 nov. 2017.

DANNER, M. A.; ZANETTE, F.; RIBEIRO, J. Z. O cultivo da araucária para produção de pinhões como ferramenta para a conservação. Pesquisa Florestal Brasileira, Colombo, v. 32, n.72, p. 441-451, oct./nov. 2012.

FERREIRA, L. M. M.; TONINI, H. Comportamento da castanha-do-brasil (Bertholletia excelsa) e da cupiúba (Goupia glabra) em sistema agrosilvicultural na região da Confiança, Cantá-Roraima. Acta Amazonica, v. 39, n. 4, p. 835-842, 2009.

FIGUEIREDO F., A.; ORELLANA, E.; NASCIMENTO, F.; DIAS, A. N.; INOUE, M. T. Produção de sementes de Araucaria angustifolia em plantio e em floresta natural no Centro-Sul do Estado do Paraná. Floresta, Curitiba, v. 41, n. 1, p. 155-162, 2011.

GUTIERREZ, E.M.R.; REGITANO-D'ARCE, M.A.B.; RAUEN-MIGUEL, A.M. Estabilidade oxidativa do óleo bruto da castanha do Pará (Bertholletia excelsa). Ciência e Tecnologia de Alimentos, v. 17, n. 1, p. 22-27, 1997.

INSTITUTO BRASILEIRO DE GEOGRAFIA E ESTATÍSTICA - IBGE. Manual técnico da vegetação brasileira. 2.ed. Rio de Janeiro: IBGE, 2012. 270p. (Manuais técnicos em geociências, 1). 
INSTITUTO BRASILEIRO DE GEOGRAFIA E ESTATÍSTICA - IBGE. Produção da Extração Vegetal e da Silvicultura. 2017. Available in: https://sidra.ibge.gov.br/tabela/289\#resultado. Accessed in 06 nov. 2017.

MAGNANTI, N. J. A importância social e econômica do pinhão na Serra Catarinense. Povos do Campo, Educação e Natureza. Grafine Gráfica e Editora, Lages, v. 1, ed. 1 p. 57-67, 2016.

MORET, A. S.; BARBOSA M. A. M. A renda nas reservas extrativistas: situação da cadeia produtiva da castanha do brasil. Saber Científico, Porto Velho, v. 5, n. 2, p. 18-29, 2016.

NODARI, E.S.; KLUG. J. História ambiental e migrações. Oikos, São Leopoldo, p. 202, 2012.

PARRON, L.M.; GARCIA, J.R.; OLIVEIRA, E.B. DE.; BROWN, G.G.; PRADO, R.B. Serviços ambientais em sistemas agrícolas e florestais do Bioma Mata Atlântica. Embrapa, Brasília, p. 370, 2015.

PERALTA, R. M. KOEHNLEIN, E. A.; OLIVEIRA, R. F.; CORREA, V. G.; CORRÊA, R. C.G.; BERTONHA, L.; BRACHT, A.; FERREIRA, I.C.F.R. Biological activities and chemical constituents of Araucaria angustifolia: An effort to recover a species threatened by extinction. Trends in Food Science \& Technology, v. 54, p. 85-93, 2016.

PERES, C.A.; BAIDER, C.; ZUIDEMA, P.A.; WADT,L.H.O.; KAINER, K.A.; GOMES-SILVA, D.A.P.; SALOMÃO, R.P.; SIMÕES, L.L.; FRANCIOSI,E.R.N.; VALVERDE, F.C.; GRIBEL, R.; SHEPARD JR, G.H.; KANASHIRO, M.; COVENTRY, P.; YU, D.W.; WATKINSON, A.R.; FRECKL, R.P. Demographic threats to the sustainability of Brazil nut exploitation. Science, p. 2112-2114, 2003.

BRASIL. Portaria Normativa DC N.20, de 27 de setembro de 1976. Proíbe o abate de pinheiros adultos portadores de pinhas, nos meses de abril, maio e junho. Instituto Brasileiro de Desenvolvimento Florestal IBDF.1976. Available in http://oads.org.br/leis/1071.pdf. Accessed in 9 mai. 2020

RAMBO, B. A fisionomia do Rio Grande do Sul. Selbach, Porto Alegre, ed. 2, 1956.

SALOMÃO, R. P. A castanheira: história natural e importância socioeconômica. Cienc. Nat., Belém, v. 9, n. 2 , p. 259-266, may. /aug. 2014.

SANT'ANNA, C.S.; SEBBENN, A.M.; KLABUNDE, G.H.F.; BITTENCOURT, R.; NODARI, R.O.; MANTOVANI, A.; REIS, M.S. Realized pollen and seed dispersal within a continuous population of the dioecious coniferous Brazilian pine [Araucaria angustifolia (Bertol.) Kuntze]. Conservation Genetics, v. 14, p. 601-613, 2013.

SCHÖNGART, J.; GRIBEL, R.; FONSECA-JUNIOR, S. F.; HAUGAASEN, T. Age and growth patterns of Brazil nut trees (Bertholletia excelsa Bonpl.) in Amazonia, Brazil. Biotropica, v. 47, n. 5, p. 550-558, 2015.

SILVA, C.V. DA; MIGUEL, L.DE A. Os canais de comercialização do pinhão e seus agentes, em São Francisco de Paula, RS. Floresta, Curitiba, v. 47, n. 4, p. 489-500, oct./dec 2017.

THOMAS, E.; CAICEDO, C. A.; LOO, J.; KINDT, R. The distribution of the Brazil nut (Bertholletia excelsa) through time: from range contraction in glacial refugia, over human-mediated expansion, to anthropogenic climate change. Boletim do Museu Paraense Emílio Goeldi Ciências Naturais, v. 9, n. 2, p. 267-291, 2014.

ZANETTE, F.; DANNER, M. A.; CONSTANTINO, V.; WENDLING, I. Particularidades, biologia reprodutiva e hábitos de crescimento em plantas de Araucaria angustifolia. Araucária: particularidades, propagação e manejo de plantios. Brasilia, Embrapa, v. 1, p. 15-42, 2017.

WADT, L. H. O.; KAINER, K. A. Domesticação e Melhoramento de Castanheira. Domesticação e Melhoramento: Espécies Amazônicas. Viçosa, Cap. 15, p. 298-317, 2009. 